\title{
Evaluation of Water Sanitation Health Education Programme: Working with the Knowledge of the Basic Sanitation Services in a Developing Community in Rural Haiti after the 2010 Earthquake
}

VE Reyes-Ortiz, W Calderón-Alicea, R Castillo, JJ Cintrón-García, JJ Cintrón-García, L Colón Cruz, A Hernández-Muñoz, I Irizarry-Pérez, I Lockward, C Neste-Laboy, M Ortíz-León, A Peréz-Homar, J Pérez, W Ramírez-López,

L Rivera, D Scholz, M Soto-Ortíz, A Torres-García

\begin{abstract}
Objective: The aim of this study is to measure the knowledge regarding the new sanitation water system being implemented in Dessources, a rural community in the municipality of Croix-des-Bouquets in Haiti after a two-year intervention programme.

Design and Methods: A cross-sectional epidemiologic design was used to measure the knowledge of the people in the community using a semi-structured questionnaire. Data collection followed a face-to-face interview process in all houses of the community. The instrument content validity was performed by a panel of experts followed by Cronbach's alpha test to establish the reliability of knowledge scale. In addition, association measures were done using Stata 11.0 statistical package.

Results: Content validity tests were performed with minimum changes and an alpha of 0.74 was obtained for the scale. Response rate was $65.57 \%$ (41/60 houses); non-participants were only those who did not meet the inclusion criteria. Most of the participants (77.5\%) were 21-49 years old and $85 \%$ had been living in the community for more than 20 years. Bivariate analysis showed that the people of Dessources had adequate knowledge. Significant differences, however, were found among the zones that are not in use of the new sanitary systems and among families with more than seven members per house. Conclusions: Differences found can be explained based on the Rogers theoretical diffusion of innovation model. The evaluation shows that people of Dessources in Haiti have a high knowledge regarding the new water sanitation system and provides evidence of an adequate health education programme intervention.
\end{abstract}

Keywords: Haiti, health education, sanitation, water

\section{Evaluación del Programa de Educación para la Salud con Respecto al Saneamiento de Agua: Trabajando con Conocimiento de los Servicios Básicos de Saneamiento en una Comunidad en Vías de Desarrollo en Zonas Rurales de Haití después del Terremoto de 2010}

VE Reyes-Ortiz, W Calderón-Alicea, R Castillo, JJ Cintrón-García, JJ Cintrón-García, L Colon Cruz, A Hernández-Muñoz, I Irizarry-Pérez, I Lockward, C Neste-Laboy, M Ortíz-León, A Peréz-Homar, J Pérez, W Ramírez-López, L Rivera,

D Scholz, M Soto-Ortíz, A Torres-García

\section{RESUMEN}

Objetivo: El objetivo de este estudio es medir el conocimiento sobre el nuevo sistema de saneamiento del agua que está siendo implementando en Dessources, una comunidad rural en el municipio de Croixdes-Bouquets en Haití, después de un programa de intervención de dos años.

From: Health Services Administration Department, Graduate School of Public Health, Medical Sciences Campus, University of Puerto Rico, San Juan, Puerto Rico.

Correspondence: Dr VE Reyes-Ortiz, Health Services Administration Department, Medical Sciences Campus, Graduate School of Public Health,
University of Puerto Rico, San Juan, Puerto Rico. E-mail: victor.reyes4 @upr.edu

* The abstract of this article was presented at the Caribbean Public Health Agency's $58^{\text {th }}$ Scientific Meeting; Barbados; May 2-4, 2014 and published in West Indian Med J 2013; 62 (Suppl 2): 78. 
Diseño y Métodos: Se utilizó un diseño epidemiológico transversal para medir el conocimiento de las personas en la comunidad mediante un cuestionario semiestructurado. La recopilación de datos siguió a un proceso de entrevistas cara a cara en todas las casas de la comunidad. La validez del contenido del instrumento fue realizada por un panel de expertos, seguida por la prueba alfa de Cronbach para establecer la confiabilidad de la escala de conocimientos. Además, se realizaron medidas de asociación utilizando el paquete estadístico STATA 11.0.

Resultados: Las pruebas de validez del contenido se realizaron con cambios mínimos y se obtuvo un alfa de 0.74 para la escala. La tasa de respuesta fue $65.57 \%$ (41/60 casas). Solamente no participaron aquellos que no cumplían con los criterios de inclusión. La mayoría de los participantes (77.5\%) tenían 21 - 49 años de edad, y 85\% habian estado viviendo en la comunidad por más de 20 años. El análisis bivariante mostró que los moradores de Dessources poseían conocimientos adecuados. Sin embargo, se encontraron diferencias significativas entre las zonas que no tienen acceso a los nuevos sistemas sanitarios, así como entre las familias con más de siete miembros por casa.

Conclusiones: Las diferencias encontradas pueden explicarse a partir del modelo de Rogers de difusión de innovación. La evaluación muestra que la gente de Dessources en Haití tiene un elevado conocimiento en relación con el nuevo sistema de saneamiento del agua, y dio evidencias de que la intervención del programa de educación para la salud fue adecuada.

Palabras claves: Haití, educación para la salud, saneamiento, agua

West Indian Med J 2014; 63 (6): 617

\section{INTRODUCTION}

It is estimated that over one billion people in the world lack access to clean water and/or basic sanitary services (1). Sanitary services for proper human waste disposal are a basic necessity for healthy development of communities. However, human waste disposal (including excreta) still presents a global challenge for governments and affects health indicators $(2,3)$. Research reports that inadequate water and sanitation services are the second most important risk factor to be addressed to improve community health among developing countries (1). The unsafe water supplies and lack of sanitation has contributed to approximately 1.6 million deaths per year in the past decade (4). Diarrhoea, neglected diseases and parasitical infections have consistently been the most relevant health outputs associated with the sanitary deficiency since the 1980s (5-8). The World Health Organization report also describes the diarrhoea morbidity and mortality rates as one of most relevant health problems worldwide, thus calling for actions to improve water supply and excreta disposal (3).

The necessity of adequate excreta disposal could be competing with other health necessities and commodities considered as more important. Carolini posits that water sanitation could be underestimated by communities due to the lack of associations among health outcomes and water sanitation (9). Therefore, evaluation of knowledge regarding water sanitation systems in a community is necessary to help reduce child mortality, improve mothers' health and improve the quality of life in slum populations (4). In this project, the authors aimed to measure the knowledge regarding the new sanitation water system being implemented in Dessources, a rural community in the municipality of Croix-des-Bouquets in Haiti. Evaluation was guided using the Rogers diffusion of innovation (DOI) theory (10).

\section{SUBJECTS AND METHODS}

During the summer of 2012, a cross-sectional epidemiologic design was used to measure the knowledge of the people in the community using a semi-structured questionnaire. The semi-structured questionnaire had 56 items divided in three parts: (a) sociodemographic profile, (b) knowledge and (c) the toilette à compost's attributes. The sociodemographic profile consists of nine questions. The knowledge section has 11 questions and 36 questions are related to the toilette $a$ compost's attributes. For this paper, only those questions related to knowledge are discussed.

Data collection followed a face-to-face interview process, where participants were asked to complete the survey within their houses. Completeness of the questionnaire was performed by participants in front of investigators and in companion of translators in case any question arose. All adults living in the community that complied with the following inclusion criteria were asked to participate: (a) being an adult between 21 and 60 years old, (b) has been living in Dessources for at least two years and (c) being a Kriol, French or English speaking person. Any subject that appeared to have mental, cognitive or a language disability was excluded from the study. If participants were not in the house at the time of the survey, a second visit was performed in order to increase response rate.

Last, as this instrument has previously not been used, no reliability and content validity test had been performed. Cronbach's alpha was used to establish the reliability of knowledge scale. Content validity to assure readability and 
comprehensibility of the questionnaire was performed by a group of specialists in environmental health, community leaders and a psychometric expert. Content validity included a back translation from English to Kriol and Kriol to English to assure each question was understandable. In addition, association measures were done using Chi-squared and oneway analysis of variance (ANOVA) tests for multivariate analysis. Stata 11.0 statistical package was used to analyse all data.

\section{RESULTS}

Participants' knowledge was measured using 11 items on a Guttmann scale (yes/no). The Cronbach's alpha for the scale was 0.74 and no item was eliminated from the scale. Response rate was $65.57 \%$ (41/60 houses); non-participants were only those who did not meet the inclusion criteria. Most of the participants $(77.5 \%)$ were $21-49$-years old and $85 \%$ had been living in the community for more than 20 years. After recoding correct or incorrect answers, the scale was added, producing an 11-point scale that ranged from 0-11. A total score of seven was considered adequate knowledge and less than seven points was considered inadequate. Scores obtained by the community averaged 8.7 (range $1-11$ points), showing an appropriate knowledge regarding the sanitation water system implemented.

Bivariate analysis showed that none of the demographic variables measured was associated with significant differences in knowledge. Only the total persons living within a house was reported to be significantly associated with knowledge $\left[\chi^{2}(\mathrm{gl}=2)=5.4902, p=0.049\right]$. One-way ANOVA test showed that there were statistically significant differences in the knowledge reported among those areas using the water sanitation system and those areas in the community where it had not been implemented $F=4.21, p$ $=0.0225$ ).

Multiple linear regression showed that the model explained $65 \%$ of the variance among variables. Statistically significant variables in this analysis $(p<0.05)$ were: (a) those less than 30 years in comparison with those 40-49 years had significantly lower knowledge $[\beta=-2.08]$, (b) those living in Zone 2 in comparison with those living in Zone 1 where the toilette à compost was installed had more knowledge $(\beta=$ -2.07) and (c) those who reported to have heard about the toilette à compost had significantly higher knowledge $(\beta=$ 8.15).

\section{DISCUSSION}

After two years of intervention with different health education and health promotion strategies, the people of Dessources showed adequate knowledge regarding the new water sanitation system. The only significant differences observed were between those having the water sanitation system implemented and those who did not; those younger than vs those 40-49 years old; and those who knew the innovation existed. This can be fully explained by Rogers
DOI theory that states that knowledge consists of three dimensions: (a) knowledge that the innovation exists, (b) procedural knowledge, which deals with the knowledge of how to use the new technology and (c) principles knowledge, one that explains how the innovation works (10). Thus, it is expected that those who had the new water sanitation system and knew it existed had an increased level of knowledge.

The literature posits that younger persons adapt better to new technologies and older persons have more difficulty adapting to the innovation (11). In contrast to our data, after controlling multiple variables, those who were 40-49 years old seemed to hold higher knowledge. This could be explained by the fact that this age group worked directly in the building of the toilette à compost and had observed the long-term effects of lacking a proper sanitary system.

This study also suggests that the diffusion of the knowledge is slower in those family groups that are bigger than seven members. This is also in accordance with the Rogers' theory, in which size is directly related to the diffusion of the new technology. Morales also posited that the learning process in smaller groups is more effective and shows higher efficacy levels (12). For our community, this means that family groups with more than six persons had lower diffusion rates.

The evaluation suggests that people of Dessources in Haiti have a high knowledge regarding the new water sanitation system and give evidence of adequate health education programme intervention. Therefore, based on the DOI theory, the programme has good chances of becoming sustainable within the community of Dessources in Haiti.

In conclusion, after two years of the health education programme, the interventions were successfully increasing the community knowledge. Also, statistical analysis showed that gaps in the knowledge can be explained by the Rogers DOI model.

\section{REFERENCES}

1. Pattanayak SK, Poulos C, Yang JC, Patil S. How valuable are environmental health interventions? Evaluation of water and sanitation programmes in India. Bull World Health Organ 2010; 88: 535-42.

2. United Nations. The Milennium Development Goals Report 2011 [Internet]. New York: United Nations: 2011 Jun 1 [rev 2011 Dec 15; cited 2012 May 3]. Available from: http://www.un.org/ millenniumgoals/pdf/(2011_E)\%20MDG\%20Report\%202011_Book\% 20LR.pdf

3. World Health Organization. Estadísticas sanitarias mundiales 2011 [Internet]. Geneva: WHO; 2011 Jun 1 [rev 2011 Dec 15; cited 2012 May 3]. Available from: http://www.who.int/whosis/whostat/ ES_WHS2011_Full.pdf

4. Hutton G, Bartram J. Global cost of attaining the millennium development goal for water supply and sanitation. Bull World Health Organ 2008; 86: 13-9.

5. Mascarini-Serra L. Prevention of soil-transmitted helminth infection. J Glob Infect Dis 2011; 3: 175-82.

6. Batterman S, Eisenberg J, Hardin R, Kruk ME, Lemos MC, Michalak $\mathrm{AM}$ et al. Sustainable control of water-related infectious diseases: a review and proposal for interdisciplinary health-based systems research. Environ Health Perspect 2009; 117: 1023-32. 
7. Holveck JC, Ehrenberg JP, Ault SK, Rojas R, Vasquez J, Cerqueira MT et al. Prevention, control, and elimination of neglected diseases in the Americas: pathways to integrated, inter-programmatic, inter-sectorial action for health and development. BMC Public Health 2007 [rev 2011 Dec 15; cited 2012 May 3]; 7: 6. Available from: http://www.ncbi. nlm.nih.gov/pmc/articles/PMC1797008/pdf/1471-2458-7-6.pdf

8. Esrey SA, Feachem RG, Hughes JM. Interventions for the control of diarrheal diseases among young children: improving water supplies and excreta disposal facilities. Bull World Health Organ 1985; 63: 757-72.

9. Carolini G. Framing water, sanitation, and hygiene needs among female-headed households in Periurban Maputo, Mozambique. Am J Public Health 2012; 102: 256-61.
10. Ederberg M. Essentials of health behavior: social and behavioral theory in public health. Maryland, USA: Jones and Barlett; 2007.

11. Sjölinder M, Höök K, Nilsson L, Anderson G. Age differences and the acquisition of spatial knowledge in a three-dimensional environment: evaluating the use of an overview map as navigation aid. Intl J Hum Comput Stud 2005; 63: 537-64.

12. Morales C. Mejores resultados en grupos pequeños. [rev 2011 Dec 15; cited 2012 May 3]. Available from: http://www.oficial-1.webarchive. com 